Vol. 13 (2004): 295-308.

\title{
Relationships between climate and winter cereal grain quality in Finland and their potential for forecasting
}

Philip D. Hollins, Peter S. Kettlewell

Harper Adams University College, Crop and Environment Research, Newport, Shropshire, TF10 8NB, England,

e-mail:phollins@harper-adams.ac.uk

Pirjo Peltonen-Sainio

MTT Agrifood Research Finland, Plant Production Research, FI-31600, Jokioinen, Finland

Mark D. Atkinson

Harper Adams University College, Crop and Environment Research, Newport, Shropshire, TF10 8NB, England

\begin{abstract}
Many studies have demonstrated the effects of climate on cereal yield, but there has been little work carried out examining the relationships between climate and cereal grain quality on a national scale. In this study national mean hectolitre weight for both rye and winter wheat in Finland was modelled using monthly gridded accumulated snow depth, precipitation rate, solar radiation and temperature over the period 1971 to 2001 . Variables with significant relationships in correlation analysis both before and after difference detrending were further investigated using forward stepwise regression. For rye, March snow depth, and June and July solar radiation accounted for $66 \%$ of the year-to-year variance in hectolitre weight, and for winter wheat January snow depth, June solar radiation and August temperature accounted for $62 \%$ of the interannual variance in hectolitre weight. Further analysis of national variety trials and weather station data was used to support proposed biological mechanisms. Finally a cross validation technique was used to test forecast models with those variables available by early July by making predictions of above or below the mean hectolitre weight. Analysis of the contingency tables for these predictions indicated that national hectolitre weight forecasts are feasible for both cereals in advance of harvest.
\end{abstract}

Key words: cereals, forecasts, hectolitre weight, models, precipitation, quality, rye, snow depth, solar radiation, specific weight, test weight, temperature, wheat

\section{Introduction}

Lying between $60^{\circ}-70^{\circ}$ north, Finland is the most northerly agricultural country in the world. Mean temperatures are several degrees higher than areas occupying similar latitudes (e.g. Siberia and southern Greenland). This is due partly to the proximity of the Baltic Sea, but predominantly through the effect of the Gulf Stream, warming 


\section{Hollins, P.D. et al. Relationships between climate and winter cereal grain quality}

westerly airflow from the Atlantic. The climate is characterised by long winters, with permanent snow depth in the central region lasting, from mid November through to early May. This is followed by a short summer season, before the start in September, of inclement autumn weather.

The cereal-growing season in Finland (defined as the period with mean daily temperature above $\left.5^{\circ} \mathrm{C}\right)$ varies greatly: in the south $\left(60^{\circ} \mathrm{N}\right)$, between 170 and 180 days and in the north $\left(67^{\circ} \mathrm{N}\right.$ - the practical limit for cereal growth), between 130 and 135 days (Mukula and Rantanen 1987). This compares with a mean growing season of over 250 days for most of central Europe. This short growing season limits crop yields and places considerable constraint on the type of crop and the region cultivated. However, long summer days do result in rapid cereal growth and development, enabling cereal harvest before the onset of unfavourable early autumn climatic conditions.

Compared to spring sown cereals, over-wintering cereals offer the possibility of greater yields. In Finland, over-wintering cereals need to be particularly hardy and well adapted to withstand the harsh winter months, together with the uncertainty of early spring frosts. Currently 58,000 hectares (Finfood 2002) of winter cereals are grown in Finland, but climatic uncertainty can result in large inter-annual fluctuations in the area sown, in the over-wintering survival rate and in cereal quantity and quality at harvest time. However, despite these difficulties, it has been speculated that in coming decades the potential exists for increased cultivation of over-wintering cereals, from projected climate warming (Mela 1996).

Rye and winter wheat are both over-wintering cereals. Rye is typically sown in the latter part of August, and harvested early in the following August. Wheat is generally sown, in late August or early September with harvest also in the following August. Considerable work has been carried out to identify the recommended geographical extent of these cereal growth regions. Studies by Mukula and Rantanen (1989a, b) assessed crop potential, the suitability of a region for crop cultivation, for rye and winter wheat using annual yield data and meteorological data over 25 years. Rye is known to be better adapted to the climatic conditions than winter wheat and thus can be successfully grown in a larger cereal growth region $\left(60-65^{\circ} \mathrm{N}\right)$ compared to that for winter wheat $\left(60-61.50^{\circ} \mathrm{N}\right)$. For both cereals, climatic risk becomes acute in the marginal northern extremities of their respective growth regions. For rye this is particularly evident, with more than $95 \%$ of rye cultivation occurring below $64^{\circ} \mathrm{N}$ (Finfood 2002).

For rye and winter wheat, there are many historical and contemporary studies, investigating grain yield in relation to weather. Studies have been carried out throughout Europe, for rye in Finland (Saarikko 2000); Germany (Chmielewski and Kohn 2000); Hungary (Marton 2002) and for winter wheat in Britain (Hooker 1922); Spain (Lloveras et al. 2001) and Yugoslavia (Mladenov and Przulj 1999). In contrast, less work has been carried out examining the relationships between cereal grain quality and the weather.

High quality grain is a requirement of the bread milling industry and as with grain yield, grain quality is also affected directly by the weather. In Finland annually, there is a cereal payment scheme for farmers based on recognised quality parameters, measured during the harvest season. Farmers with high quality grain receive additional payment, whereas those farmers with lower grain quality receive a reduced payment. Clearly it is in the financial interest of the farmer to produce as high quality grain as is possible.

Hectolitre weight is a grain quality parameter and is the weight of a fixed volume of grain $\left(\mathrm{kg} \mathrm{hl}^{-1}\right)$. It is often used as an approximate measure of the expected flour yield (Halverson and Zeleny 1988) and also has an impact on grain transport and storage costs (Brooker et al. 1992). Few studies have examined the influence of climate on hectolitre weight at a national scale, over seasonal periods. Results from Britain, where studies have been carried out investigating wheat national hectolitre weight and climate, (Kettlewell et al. 2003) indicate that summer sun- 
Vol. 13 (2004): 295-308.

shine and precipitation are the most important factors.

The aim of this study was to develop climatic models, appropriate to the relevant cereal growth region, for rye and winter wheat national annual mean hectolitre weight in Finland from 1971 to 2001.

\section{Material and methods}

Annual national mean hectolitre weight values for both rye and winter wheat were obtained from 1971 to 2001 from The Plant Production Inspection Centre, Helsinki, Finland (Fig. 1). These data are representatively sampled and collated from all significant rye and winter wheat growing regions within Finland. The data are published in a series of annual reports (Grain Laboratory of State Granary 1971-1991, Plant Production Inspection Centre 1994-2001), which also give the number of observations associated with each value.

The climatic data were obtained from the National Centre for Environmental Prediction and National Centre for Atmospheric Research (NCEP - NCAR) reanalysis data set, available from The National Oceanic Atmospheric Administration (NOAA) climate diagnostics centre website (http://www.cdc.noaa.gov). These data consist of observations, interpolated data and numerical model output, giving the most reliable and complete global gridded dataset currently available (Kalnay et al. 1996). Since their inception, these datasets have become one of the primary research tools in use by climatologists worldwide. Monthly data are available at a resolution of $1.875^{\circ}$ longitudinal by latitude grids. From these data sets precipitation rate $\left(\mathrm{kg} \mathrm{m}^{-2} \mathrm{~s}^{-1}\right)$, near surface temperature $\left({ }^{\circ} \mathrm{C}\right)$, accumulated snow depth $\left(\mathrm{kg} \mathrm{m}^{-3}\right)$ and downward solar radiation (W $\mathrm{m}^{-2}$ ) were extracted from 1971 to 2001 . The climatic data were obtained for the longitude $x$ latitude defined grids shown in Figure 2. For each climatic variable, a monthly mean figure was calculated from the extracted monthly gridded values. In the larger rye region, 18 monthly values were used in calculating the monthly mean, in the smaller winter wheat region, 12 monthly data values used for this calculation.

Having checked all variables for normality, initial correlation analysis was carried out to in-
Fig. 1. Time series for Finnish national annual mean hectolitre weight $\left(\mathrm{kg} \mathrm{hl}^{-1}\right)$ for over wintering cereals: rye (continuous line) and winter wheat (broken line). Linear regression lines fitted to indicate trend.

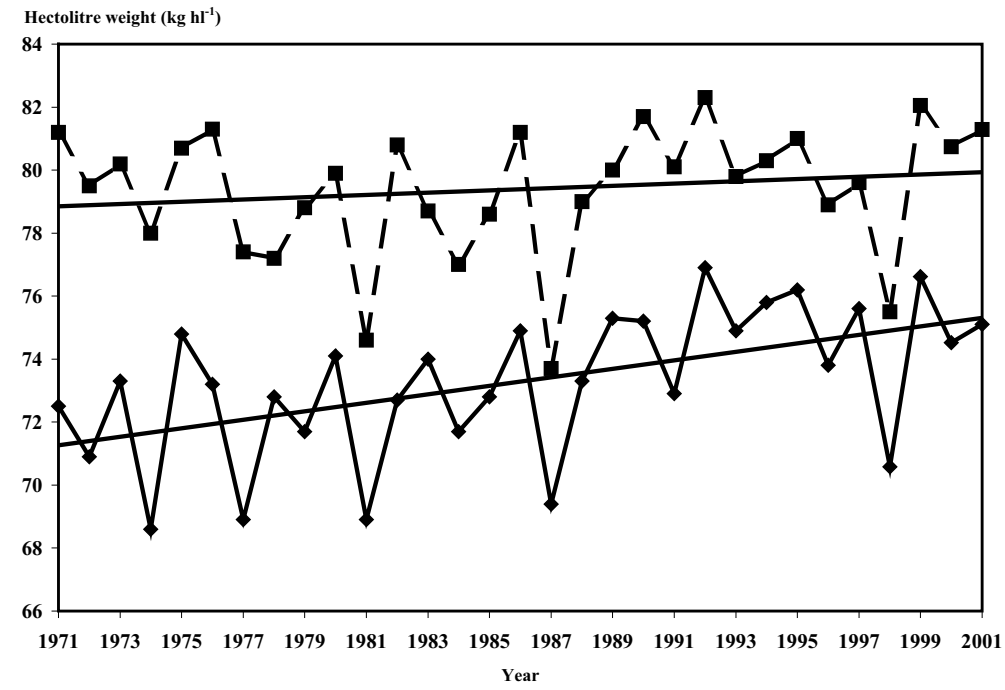




\section{Hollins, P.D. et al. Relationships between climate and winter cereal grain quality}

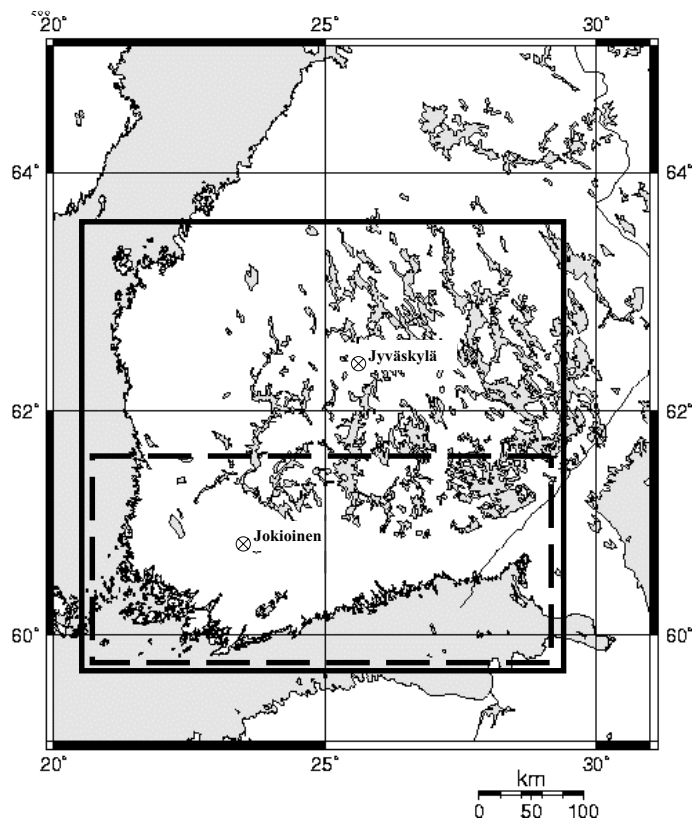

Fig. 2. NCAR/NCEP climatic data grid squares (resolution $\left.1.875^{\circ}\right)$ used for modelling: rye continuous line $\left(20.6^{\circ} \mathrm{E}\right.$ to $30.0^{\circ} \mathrm{E}, 60.0^{\circ} \mathrm{N}$ to $63.8^{\circ} \mathrm{N}$ ) and winter wheat broken line $\left(20.6^{\circ} \mathrm{E}\right.$ to $30.0^{\circ} \mathrm{E}, 60.0^{\circ} \mathrm{N}$ to $\left.61.9^{\circ} \mathrm{N}\right)$. Two weather stations used for model interpretation are located at Jokioinen $\left(60.82^{\circ} \mathrm{N}, 23.50^{\circ} \mathrm{E}\right)$ and Jyväskylä $\left(62.40^{\circ} \mathrm{N}, 25.68^{\circ} \mathrm{E}\right)$. Map adapted from: OMC (http://www.aquarius.geomar.de/omc/ omc_intro.html).

vestigate the possible relationships between the annual mean hectolitre weights of rye and winter wheat against the individual monthly mean climatic variables from the respective growth regions of these cereals.

A correlation between variables recorded over the same time period can show misleading significance if both variables display coincident long-terms trends, yet have minimal short-term year to year interrelationship. To remove the possibility that such trends inherent in the data were responsible for spurious correlation results, all variables were detrended by calculating year to year differences (Stephenson et al. 2000). For each variable, the value in the previous year was subtracted to give the first order difference, this was repeated for every year (except the first year). Once all variables were differenced, correlation coefficients were then calculated. Only those correlations coefficients significant $(\mathrm{P}<$ 0.05 ) before and after difference detrending were considered robust.

Those monthly mean climatic variables identified as having a significant relationship with hectolitre weight were further investigated to establish possible explanatory models. Forward stepwise selection multiple linear regression was used, with national annual mean hectolitre weight as a response variable against explanatory mean monthly climatic variables, with $\mathrm{P}=$ 0.05 as the criterion for inclusion of explanatory variables. All regression models were weighted using the annual sample number from the national cereal survey and all model residuals were checked for normality. For difference detrended data, the reciprocal of the sums of successive national annual sample numbers was used as the weight variable. After all these criteria were satisfied, only those regression models significant $(\mathrm{P}<0.05)$ before and after difference detrending were considered robust.

Further correlation analysis was undertaken to investigate the relationship between the annual hectolitre weights from the national survey data and those from the national variety trial data. The national variety trials data was obtained from 1971 to 2001 from MTT Agrifood research, Jokioinen, Finland and are collated from field trials that simulate practical cultivation from up to 16 sites from across Finland. These data contain detailed crop lifecycle information, which are used to determine the suitability of new cereal varieties prior to general release. Existing varieties are also sown for reference. The data are available as a series of annual reports (Agricultural Research Centre of Finland 1971-2001).

Finally mean daily temperature $\left({ }^{\circ} \mathrm{C}\right)$, precipitation $(\mathrm{mm})$ and solar radiation $\left(\mathrm{kj} \mathrm{m}^{-2}\right)$ values were obtained from two weather stations: Jyväskylä $\left(62.40^{\circ} \mathrm{N}, 25.68^{\circ} \mathrm{E}\right)$ located in the rye growth region and Jokioinen $\left(60.82^{\circ} \mathrm{N}, 23.50^{\circ} \mathrm{E}\right)$ located in both rye and winter wheat regions (Fig. 2). Time series for each site were constructed using the daily long-term mean (1971-2001) for 
Vol. 13 (2004): 295-308.

all three climatic variables. These time series were used for model interpretation.

To access the predictive skill of these models and to reduce the artificial skill caused when forecasts are made from regressions using the entire dataset, a cross-validation method was used. This involves forecasting through alternate omission; data from the first year is omitted, and the regression coefficient calculated and used to forecast hectolitre weight for that omitted year. This is repeated omitting subsequent years until every year is forecast. Both the observed and cross-validated forecasted values are then categorised as either above or below the long-term hectolitre weight mean.

\section{Results and discussion}

\section{Correlation analysis}

Annual national mean hectolitre weight for rye and winter wheat are strongly correlated $(\mathrm{r}=$ 0.76, $\mathrm{P}<0.01, \mathrm{n}=31$ ). Regression lines (Fig. 1) indicate that both cereals display coincident upward trends with time. Difference detrending the cereal hectolitre weight values does not adversely affect this strong relationship $(\mathrm{r}=0.86, \mathrm{P}<$ $0.01, \mathrm{n}=30$ ).

The correlation coefficients between annual national mean hectolitre weight and monthly mean climatic variables were broadly consistent before and after difference detrending (Table 1). For rye the coefficients support negative relationships for cereal hectolitre weight with snow depth and summer precipitation and positive relationships with spring temperatures and summer solar radiation. For winter wheat, there are fewer significant correlations between hectolitre weight and climate than for rye, but there is evidence for significant negative relationships with snow depth and precipitation in June and positive relationships with temperature in spring and August and solar radiation in April, July and August. To understand the biological mecha- nisms necessary to underpin these correlation coefficients, the physiology determining hectolitre weight must be considered.

\section{Solar radiation}

For summer solar radiation the positive correlation coefficients are attributable to the wellknown fact that high solar radiation enhances photosynthesis and also thereby the synthesis of carbohydrates used for grain filling post-anthesis (Brocklehurst et al. 1978). Carbohydrates are the main constituents of cereal grains, so that correlations with hectolitre weight are expected since hectolitre weight is often considered as a indicator of how well filled or tightly packed these grains are (Bayles 1977).

\section{Precipitation rate}

Precipitation rates in July and August gave negative correlation coefficients with hectolitre weight. In the post-anthesis period drought often results in smaller grain size due to enhanced maturation of plant stands, but this does not necessarily result in reduced hectolitre weight, as in addition to grain size, hectolitre weight is dependent on packing efficiency. The findings of Bracken and Bailey (1928) demonstrated that during the latter stages of grain maturation, alternate wetting and drying of the grain surface causes the kernel to crack and wrinkle, reducing grain packing efficiency and thus hectolitre weight.

The negative coefficient for precipitation in June was unexpected - rain at this time might be expected to improve specific weight rather than reduce it by supplementing soil water reserves and reducing drought stress. This negative relationship most likely relates to crop development and specifically the rate of floret set. The critical period for yield determination in Finland is considered to be June, with the yield component reported to have the greatest influence being the number of grains per head or square metre (Peltonen-Sainio et al. 2003). Drought occurring in this development phase would typically result in a marked reduction in the number of fertile florets (Morgan 1980, Peltonen-Sainio 1991, West- 
Hollins, P.D. et al. Relationships between climate and winter cereal grain quality

Table 1. Correlation coefficients, between annual national mean hectolitre weight $\left(\mathrm{kg} \mathrm{hl}^{-1}\right)$ for rye and winter wheat in Finland (1971-2001) and monthly mean climatic variables: accumulated snow depth $\left(\mathrm{kg} \mathrm{m}^{-2}\right)$, surface temperature $\left({ }^{\circ} \mathrm{C}\right)$, precipitation rate $\left(\mathrm{kg} \mathrm{m}^{-2} \mathrm{~s}^{-1}\right)$, downward solar radiation $\left(\mathrm{W} \mathrm{m}^{2}\right)$.

\begin{tabular}{|c|c|c|c|}
\hline Climatic variable & Month & Rye $\left(\mathrm{kg} \mathrm{h}^{-1}\right)$ & $\begin{array}{l}\text { Winter wheat } \\
\qquad\left(\mathrm{kg} \mathrm{hl}^{-1}\right)\end{array}$ \\
\hline \multirow[t]{4}{*}{ Snow depth $\left(\mathrm{kg} \mathrm{m}^{-2}\right)$} & \multirow{2}{*}{$\begin{array}{l}\text { December } \\
\text { January }\end{array}$} & -0.16 & -0.20 \\
\hline & & $-0.46 * *$ & $-0.48 * *$ \\
\hline & February & $-0.40 *$ & -0.28 \\
\hline & March & $-0.45^{*}$ & $-0.40 *$ \\
\hline \multirow[t]{8}{*}{ Temperature $\left({ }^{\circ} \mathrm{C}\right)$} & January & -0.32 & 0.34 \\
\hline & February & 0.19 & 0.21 \\
\hline & March & $0.48 * *$ & $0.54 * *$ \\
\hline & April & $0.39 *$ & $0.44 *$ \\
\hline & May & 0.04 & -0.04 \\
\hline & June & 0.30 & 0.32 \\
\hline & July & 0.26 & 0.34 \\
\hline & August & 0.30 & $0.39 *$ \\
\hline \multirow[t]{8}{*}{ Precipitation rate $\left(\mathrm{kg} \mathrm{m}^{-2} \mathrm{~s}^{-1}\right)$} & January & -0.02 & 0.07 \\
\hline & February & 0.07 & 0.17 \\
\hline & March & 0.16 & 0.18 \\
\hline & April & 0.03 & 0.29 \\
\hline & May & -0.13 & -0.17 \\
\hline & June & $-0.43^{*}$ & $-0.55 * *$ \\
\hline & July & $-0.41 *$ & -0.33 \\
\hline & August & $-0.38^{*}$ & -0.29 \\
\hline \multirow[t]{8}{*}{ Solar radiation $\left(\mathrm{W} / \mathrm{m}^{2}\right)$} & January & -0.05 & -0.16 \\
\hline & February & 0.02 & -0.03 \\
\hline & March & -0.22 & -0.19 \\
\hline & April & -0.18 & $-0.37 *$ \\
\hline & May & 0.11 & 0.09 \\
\hline & June & $0.56 * *$ & $0.65 * *$ \\
\hline & July & $0.45 * *$ & 0.23 \\
\hline & August & $0.45 * *$ & $0.37 *$ \\
\hline
\end{tabular}

Areas shaded indicate significant correlations before and after difference detrending.

* Significant at $\mathrm{P}<0.05$

** Significant at $\mathrm{P}<0.01$

gate et al. 1996). If followed subsequently by sufficient rain during the early grain-filling phase these grains would be more capable of completely filling their grains compared to the high competing number of sinks in crops not previously droughted (Peltonen-Sainio et al. 2003) - this would increase hectolitre weight. The recorded effect of June rain may also partly arise from a negative association between rainfall and solar radiation due to cloudiness $(\mathrm{r}=-0.85, \mathrm{P}<0.01$, $\mathrm{n}=31$ ). Similar negative relationships between summer precipitation and national annual mean hectolitre weight have been demonstrated in the UK (Kettlewell et al. 2003).

\section{Temperature}

For summer temperature, the lack of significant and consistent positive correlations appears ini- 
Vol. 13 (2004): 295-308.

tially surprising. Temperature does evidently influence kernel growth by controlling both rate and duration of endosperm cell division and endosperm packing (Jones et al. 1985, Tashiro and Wardlaw 1991, Keeling et al. 1993), but the influence of temperature on hectolitre weight is relatively small compared to summer precipitation and solar radiation. In recent controlled environment experiments by Gooding et al. (2003) both drought and increased temperature between anthesis and the end of grain filling were seen to reduce hectolitre weight, but the reduction from drought was far greater that that from temperature. In contrast, spring temperatures, occurring well in advance of the grain-filling phase, gave significant positive correlation coefficients with cereal hectolitre. Temperatures at this time are strongly negatively correlated with accumulated snow depth in both the rye $(\mathrm{r}=-0.85, \mathrm{P}<$ $0.01, \mathrm{n}=31)$ and winter wheat $(\mathrm{r}=-0.83, \mathrm{P}<$ $0.01, \mathrm{n}=31$ ) cereal growth regions.

\section{Accumulated snow depth}

For accumulated snow depth, a possible hypothesis for the negative correlations could be the persistence of winter snow into early spring, delaying the start of the growing season. This may affect cereal development sufficiently to delay harvest to a time in a less favourable climatic window. Mukula and Rantanen (1987) confirmed that there is an increased probability for yield and quality loss the later that cereals are harvested. This may occur due to the use of late maturing cultivars, the delay in the sowing of spring cereals and in the case of over-wintering cereals, the delay in the onset of spring regrowth.

To test this hypothesis, national variety trial data was used. From this dataset the annual mean hectolitre weights for both cereals are shown to be strongly correlated with those from the national survey dataset: rye $(\mathrm{r}=0.88, \mathrm{P}<0.01, \mathrm{n}=$ $31)$ and winter wheat $(\mathrm{r}=0.79, \mathrm{P}<0.01, \mathrm{n}=$ $31)$. This thereby allows the use of this variety trial dataset and the detailed developmental information within it, to act as a proxy for the national survey data. The dataset includes a value for annual mean growth time (number of days from sowing to harvest) for each cereal. Correlation between these values and accumulated snow depth, gave significant positive correlations (Fig. 3), suggesting that increased accumulated snow depth, results in increased annual mean growth time, which evidently means later maturity as the window for sowings in autumn is very narrow in Finland. Furthermore significant negative correlations (Fig. 4) between annual mean growth time and annual mean hectolitre weight indicated that increased growth time results in reduced hectolitre weight. Conversely, signifi-
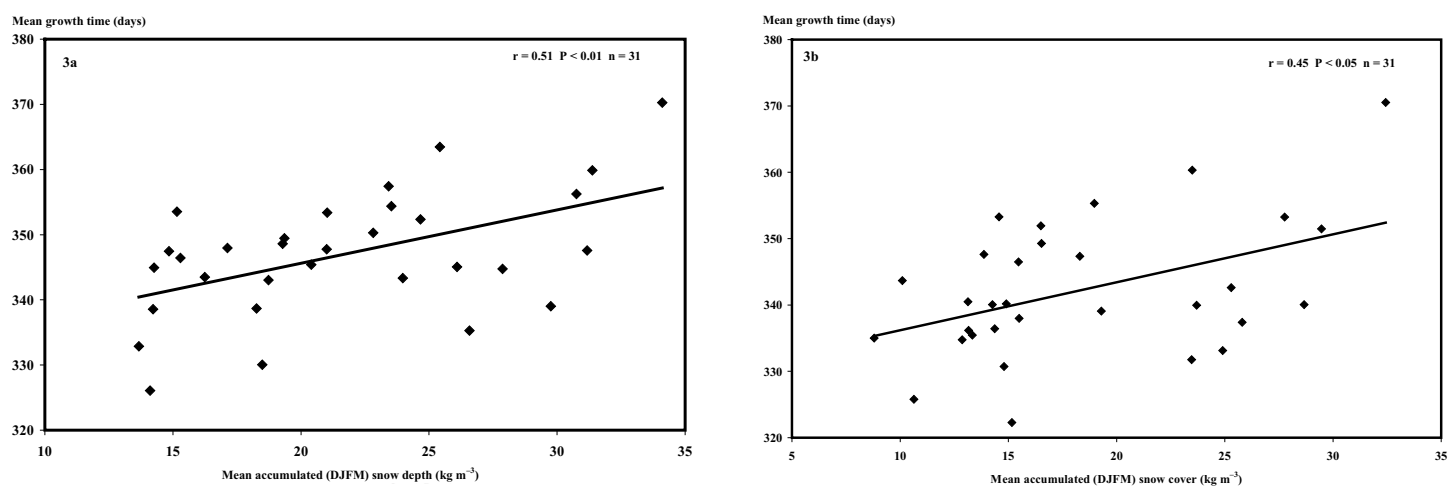

Fig. 3. Scatter plots between accumulated snow depth $\left(\mathrm{kg} \mathrm{m}^{-3}\right)$ December/January/February/March (DJFM) and annual national trial mean cereal growth time (number of days from sowing to harvest) for a) rye and b) winter wheat cereal growth regions. 
Hollins, P.D. et al. Relationships between climate and winter cereal grain quality
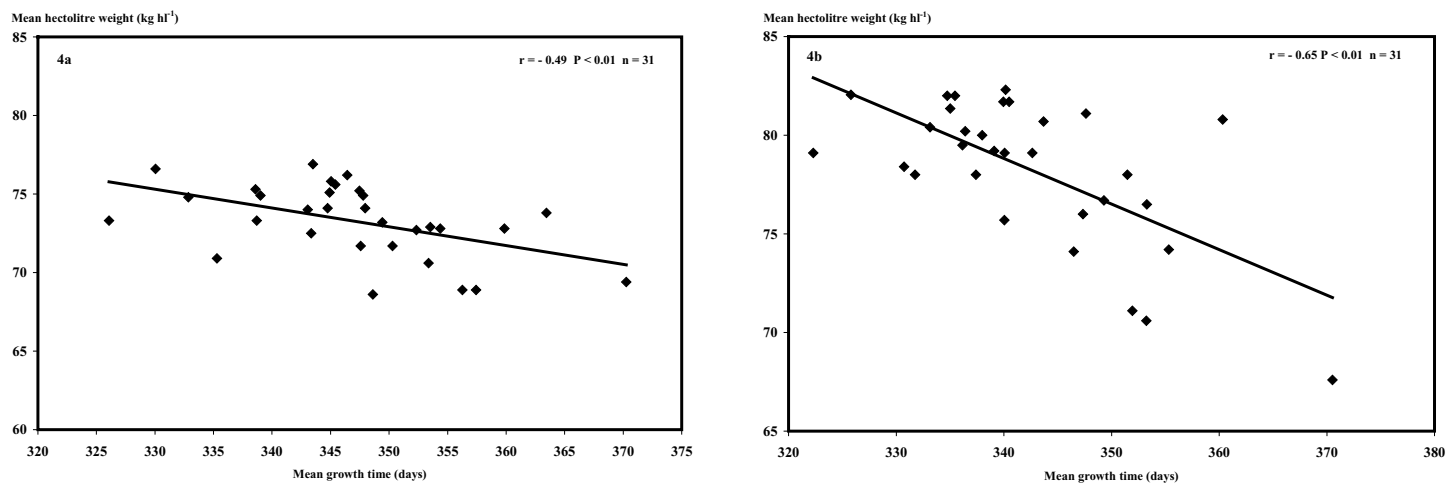

Fig. 4. Scatter plots between annual national trial mean cereal growth time (number of days from sowing to harvest) and annual national survey mean cereal hectolitre weights $\left(\mathrm{kg} \mathrm{hl}^{-1}\right)$ for a) rye and b) winter wheat cereal growth regions.
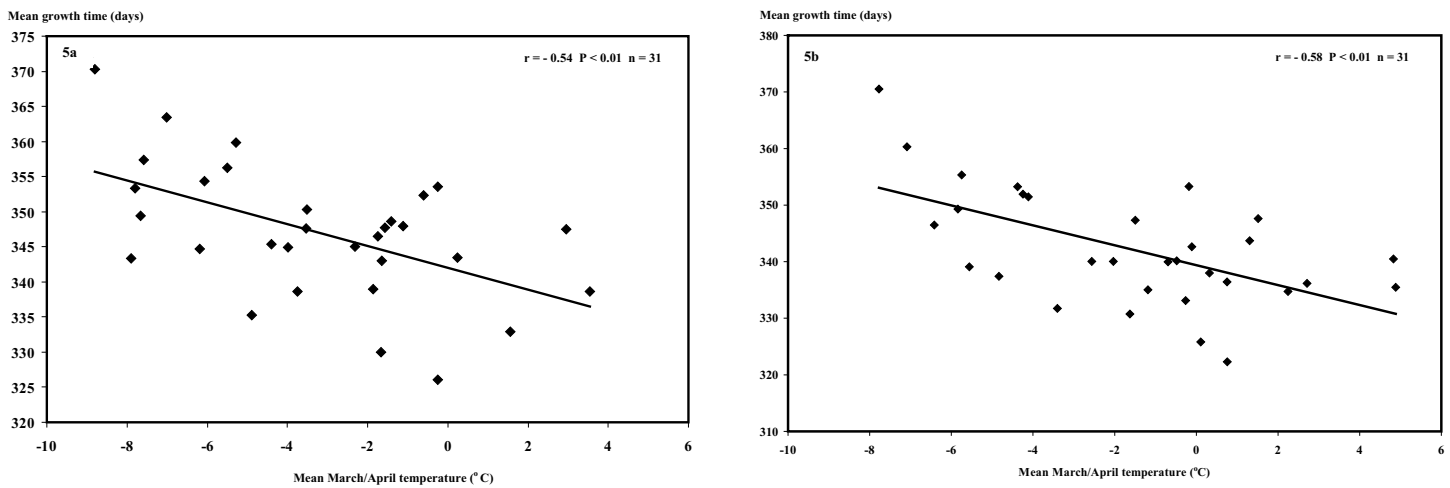

Fig. 5. Scatter plots between mean temperature $\left({ }^{\circ} \mathrm{C}\right) \mathrm{March} /$ April with annual national trial mean cereal growth time (number of days from sowing to harvest) for a) rye and b) winter wheat cereal growth regions.

cant negative correlations (Fig. 5) indicate that warmer mean spring temperatures reduce annual mean growth time (by accelerating snowmelt and the onset of spring re-growth) and as previously stated a reduced growth time results in increased hectolitre weight.

Moreover, considering the mean daily solar radiation, precipitation and temperature at two representative weather stations in August (Fig. $6)$, confirms that any minor extension of the growing season to a later harvest will be at a time of increased climatic risk. The combined effect throughout August of the decline in mean daily solar radiation and temperature for a near con- stant level of precipitation, lowers the ability of mature grain to dry by reducing potential evapotranspiration (Atzema 1993). This has the effect of delaying harvest, increasing grain weathering and hence hectolitre weight loss.

\section{Explanatory model}

The outcomes of modelling the monthly climatic explanatory variables using forward stepwise selection linear regression are displayed in Table 2 . The resultant models are consistent between cereals selecting similar winter and sum- 
Vol. 13 (2004): 295-308.
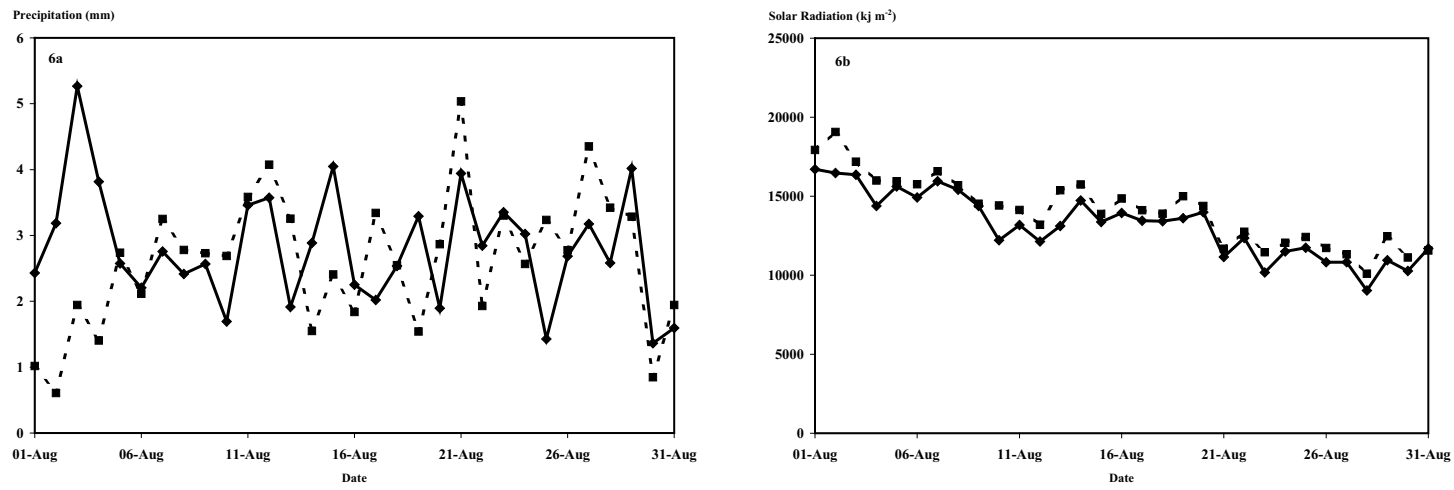

Fig. 6. Time series of mean daily a) precipitation (mm) b) solar radiation $\left(\mathrm{kj} \mathrm{m}^{-2}\right)$ and $\left.\mathrm{c}\right)$ temperature $\left({ }^{\circ} \mathrm{C}\right)$ calculated at two weather stations in Finland (1971-2000): Jokioinen $\left(60.82^{\circ} \mathrm{N}, 23.50^{\circ} \mathrm{E}\right)$ (continuous line) and Jyväskylä $\left(62.40^{\circ} \mathrm{N}, 25.68^{\circ} \mathrm{E}\right)$ (broken line).

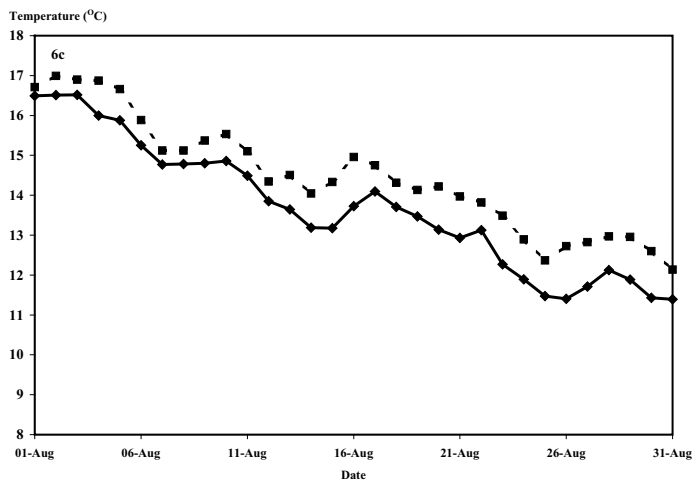

mer climatic variables that remain significant after difference detrending. By considering the percentage sum of the squares accounted for by each explanatory variable, a remarkable degree of similarity can be attributed to the respective seasonal winter and summer climatic effects influencing hectolitre weight for both cereals.

Summer solar radiation was selected in preference to summer precipitation. Recalculation of the stepwise regression models, without solar radiation, gave equivalent precipitation based models but with less variance accounted for. Clearly, solar radiation appears to be a more comprehensive model variable in determining hectolitre weight. Similarly it appears that winter accumulated snow depth offers greater model skill than spring temperature in determining hectolitre weight. August temperature was selected

for the winter wheat model in contrast to the rye model where no August climatic variable was selected. This may be a reflection of the respective different harvest times for both cereals: early August for rye and typically late August for winter wheat.

All the cereal models are in broad agreement with the findings of modelling winter wheat hectolitre weight in the UK by Kettlewell et al. (2001). They determined a regression model based on the three summer variables of June precipitation, July sunshine and August precipitation. Where these models do differ, is in the appreciable influence that winter climate has in influencing hectolitre weight. This would seem reasonable particularly in the context of the very different cereal growing conditions found in Finland. 
Hollins, P.D. et al. Relationships between climate and winter cereal grain quality

Table 2. Climatic explanatory models calculated from multiple stepwise linear regression with selected variables: accumulated snow depth $\left(\mathrm{kg} \mathrm{m}^{-3}\right)$, temperature $\left({ }^{\circ} \mathrm{C}\right)$ and downward solar radiation $\left(\mathrm{W} \mathrm{m}^{-2}\right)$ on the response variables of annual national mean hectolitre weight $\left(\mathrm{kg} \mathrm{hl}^{-1}\right)$ for two winter cereals in Finland (1971-2001). Regressions weighted using annual survey sample numbers.

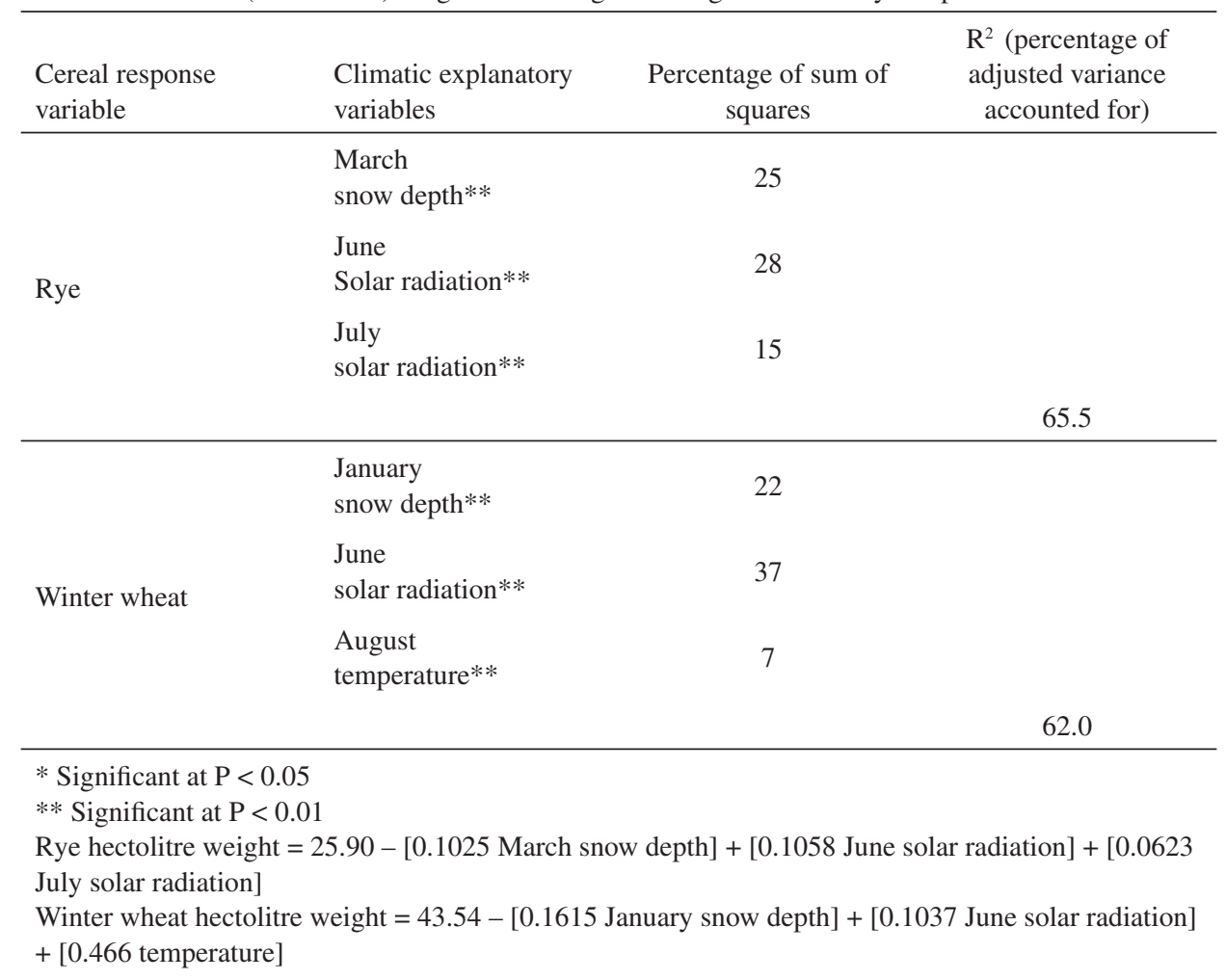

\section{Forecast model}

When considering the potential of our findings to serve as a basis for constructing hectolitre weight forecast models, clearly the earlier the forecast can be calculated, the more useful they are for prediction and utilisation by the Finnish food industry. The cereal models displayed in Table 2 offer, however, no forecast potential in their present form. However, in omitting July solar radiation and August temperature from the rye and winter wheat explanatory models, substantial variance can still be accounted for (Table 3 ) from the respective regression models to suggest that forecasts for the national mean hectolitre weight could be made by early July. This clearly is far earlier than any post harvest hectolitre weight measurement.

By taking the long term mean hectolitre of each cereal: rye $\left(73.3 \mathrm{~kg} \mathrm{hl}^{-1}\right)$ and winter wheat $\left(79.3 \mathrm{~kg} \mathrm{hl}^{-1}\right)$. It is possible using cross-validated forecast and observed values to classify each year into one of four categories; results for all the possible outcomes are displayed in Table 4 and 5. Over the entire 31 years of data the rye model correctly forecast 22 years $(72 \%)$, but the winter wheat model was slightly more successful correctly forecasting 24 years $(77 \%)$. The statistical significance of these results were tested using the odds ratio skill score (ORSS). A score of zero represents no skill whereas a score of one represents perfect skill. For rye the ORSS 
Vol. 13 (2004): 295-308.

Table 3. Climatic forecast models calculated from multiple stepwise linear regression with selected explanatory variables: accumulated snow depth $\left(\mathrm{kg} \mathrm{m}^{-3}\right)$ and downward solar radiation $\left(\mathrm{W} \mathrm{m}^{-2}\right)$ on the response variables of annual national mean hectolitre weight $\left(\mathrm{kg} \mathrm{hl}^{-1}\right)$ for two winter cereals in Finland (1971-2001). Regressions weighted using annual survey sample numbers.

\begin{tabular}{|c|c|c|c|}
\hline $\begin{array}{l}\text { Cereal response } \\
\text { variable }\end{array}$ & $\begin{array}{l}\text { Climatic forecast } \\
\text { variables }\end{array}$ & $\begin{array}{c}\text { Percentage of sum of } \\
\text { squares }\end{array}$ & $\begin{array}{l}\mathrm{R}^{2} \text { (percentage of } \\
\text { adjusted variance } \\
\text { accounted for) }\end{array}$ \\
\hline & $\begin{array}{l}\text { March } \\
\text { snow depth** }\end{array}$ & 25 & \\
\hline \multirow[t]{4}{*}{ Rye } & June & & \\
\hline & Solar radiation $* *$ & 28 & \\
\hline & & & 50.1 \\
\hline & $\begin{array}{l}\text { January } \\
\text { snow depth** }\end{array}$ & 22 & \\
\hline \multirow[t]{3}{*}{ Winter wheat } & June & & \\
\hline & solar radiation $* *$ & 37 & \\
\hline & & & 56.4 \\
\hline
\end{tabular}

* Significant at $\mathrm{P}<0.05$

** Significant at $\mathrm{P}<0.01$

Rye hectolitre weight $=43.28-[0.1077$ March snow depth $]+[0.1061$ June solar radiation $]$

Winter wheat hectolitre weight $=50.20-[0.1837$ January snow depth $]+[0.1069$ June solar radiation $]$

Table 4. Numbers of years above and below the long term mean for rye annual national mean hectolitre weight $73.3 \mathrm{~kg} \mathrm{hl}^{-1}$ in Finland for observed data and for cross-validation regression predictions (1971-2001).

\begin{tabular}{llccc}
\hline & & \multicolumn{3}{c}{ Observed } \\
\hline \multirow{3}{*}{ Forecast } & Below mean & Above mean & Total \\
& Above mean & 9 & 7 & 16 \\
& Total & 2 & 13 & 14 \\
\hline
\end{tabular}

Areas shaded indicate the correct forecast

Table 5. Numbers of years above and below the long term mean for winter wheat annual national mean hectolitre weight $79.3 \mathrm{~kg} \mathrm{hl}^{-1}$ in Finland for observed data and for cross-validation regression predictions (1971-2001).

\begin{tabular}{llccc}
\hline & & \multicolumn{3}{c}{ Observed } \\
\hline \multirow{4}{*}{ Forecast } & Below mean & Above mean & Total \\
& Below mean & 14 & 5 & 19 \\
& Above mean & 2 & 10 & 12 \\
\hline
\end{tabular}

Areas shaded indicate the correct forecast 


\section{Hollins, P.D. et al. Relationships between climate and winter cereal grain quality}

was 0.786 , for winter wheat this was 0.866 . Using Table A2 in Thornes and Stephenson (2001) confirms that at confidence levels of $95 \%$ for rye and $99 \%$ for wheat that the forecast skill is not due to chance.

These forecasts are intrinsically based on regression models. The lower the amount of variance accounted for, the weaker the predictive skill. This is clearly reflected in the rye forecast model, it has a lower forecast success rate and a bias for under-prediction, however, the winter wheat forecast model has a higher success rate and is largely unbiased in its forecasts.

A limitation of these models, is that at present the cereal growth regions used throughout this investigation are accepted approximations of the more detailed growth regions described by Mukula and Rantanen, (1989a, b). These approximations match the resolution of the gridded climatic data, but if higher resolution climate data were available, then cereal growth regions could be used which more accurately reflect the true cereal distribution. In the case of the forecast model, this may aid in its commercial applicability.

\section{Conclusion}

It has been possible to model the annual national mean hectolitre weight for winter cereals in Finland using mean monthly climatic variables. These explanatory models have been demonstrated as having robust statistical significance and not merely through coincident trends within the data.

It was found that winter accumulated snow depth and summer solar radiation accounted for the majority of the variance within these explanatory models. Snow depth was shown to have a detrimental effect on hectolitre weight by extending the growing season and delaying harvest to a less favourable climatic window. Increased solar radiation accelerates carbohydrate production for grain filling, thereby increasing hectolitre weight.
Forecast models for annual national mean hectolitre weight were also investigated. These regression models are probably too weak to produce accurate deterministic forecasts but a categorical forecast is feasible, particularly for winter wheat.

Acknowledgements. We thank the Centre for International Mobility for financial support, and Katri Pahkala and Irmeli Nissi for assistance with translation. We are also grateful to Mirja Kartio at Plant Production Inspection Centre, Grain Laboratory, for her help in compiling the quality data.

\section{References}

Agricultural Research Centre of Finland 1971-2001. Results of official variety trials. Agricultural Research Centre of Finland, Jokioinen, Finland.

Atzema, A.J. 1993. A model for the prediction of the moisture content of cereals at harvesting time with realtime weather data. Journal of Agricultural Engineering Research 54: 245-256.

Bayles, R.A. 1977. Poorly filled grain in the cereal crop. I. The assessment of poor grain filling. Journal of the National Institute of Agricultural Botany 14: 232-240.

Bracken, A.F. \& Bailey, C.H. 1928. Effect of delayed harvesting on the quality of wheat. Cereal Chemistry 5: 128-145.

Brocklehurst, P.A., Moss, J.P. \& Williams, W. 1978. Effects of irradiance and water supply on grain development in wheat. Annals of Applied Biology 90: 265276.

Brooker, D.B., Bakke, F.W. \& Hall, C.W. 1992. Drying and storage of grains and oilseeds. New York, USA: Van Nostrand Reinhold. 100 p.

Chmielewski, F.M. \& Kohn, W. 2000. Impact of weather on yield components of winter rye over 30 years. Journal of Agricultural and Forest Meteorology 102: 253261.

Finfood 2002. Agrifacts 2002. Finfood - Finnish Food Information Service, Finland. 31 p.

Gooding, M.J., Ellis, R.H., Shewry, P.R. \& Schofield, J.D. 2003. Effects of restricted water availability and increased temperature on the grain filling, drying and quality of winter wheat. Journal of Cereal Science 37: 295-309.

Grain Laboratory of State Granary 1971-1991. Research reports. Grain Laboratory of State Granary, Helsinki, Finland.

Halverson, J. \& Zeleny, C. 1988. Criteria of wheat quality. In: Pomeranz, Y. (ed.). Wheat: chemistry and technology. 3rd ed. St. Paul, Minn, USA: American Association of Cereal Chemistry. p. 19. 
Vol. 13 (2004): 295-308.

Hooker, R.H. 1922. The weather and the crops in Eastern England, 1885-1921. Quarterly Journal of the Royal Meteorological Society 48: 115-138.

Jones, R.J., Roessler, J. \& Ouattar, S. 1985. Thermal environment during endosperm cell division in maize: effects on number of endosperm cells and starch granules. Crop Science 25: 830-834.

Kalnay, E., Kanamitsu, M., Kistler, R., Collins, W., Deaven, D., Gandin, L., Iredell, M., Saha, S., White, G., Wollen, J. et al. 1996. The NCEP/NCAR 40 - year reanalysis project. Bulletin of the American Meteorological Society 77: 437-471.

Keeling, P.L., Bacon, P.J. \& Holt, D.C. 1993. Elevated temperature reduces starch deposition in wheat endosperm by reducing the activity of soluble starch synthase. Planta 191: 342-348.

Kettlewell, P.S., Atkinson, M.D., Stephenson, D.B. \& Hollins, P.D. 2001. Climatic factors mediating the effect of the winter North Atlantic Oscillation on wheat quality. Aspects of Applied Biology 64: 129-130.

Kettlewell, P.S., Stephenson, D.B., Atkinson, M.D. \& Hollins P.D. 2003. Summer rainfall and wheat grain quality: Relationships with the North Atlantic Oscillation. Weather 58: 155-164.

Lloveras, J., Lopez, A., Ferran, J., Espachs, S. \& Solsona, J. 2001. Bread-making wheat and soil nitrate as affected by nitrogen fertilization in irrigated Mediterranean conditions. Agronomy Journal 93, 6: 11831190.

Marton, L. 2002. Climate fluctuations and the effect of $N$ fertiliser on the yield of rye (Secale cereale L.). Novenytermeles 51, 2: 199-210.

Mela, T.J.N. 1996. Northern Agriculture: Constraints and responses to global climate change. Agricultural and Food Science in Finland 5: 229-234.

Mladenov, N.\& Przulj, N. 1999. Effect of winter and spring precipitation on wheat yield. Rostlinna Vyroba 45, 1: 17-22.

Morgan, J.M. 1980. Possible role of abscisic acid in reducing seed set in water-stressed wheat plants. $\mathrm{Na}$ ture 285: 655-657.
Mukula, J. \& Rantanen, O. 1987. Climatic risks to the yield and quality of field crops in Finland. I Basic facts about Finnish field crops production. Annales Agriculturae Fenniae 26: 1-18.

Mukula, J. \& Rantanen, O. 1989a. Climatic risks to the yield and quality of field crops in Finland. IV Winter wheat 1969-1986. Annales Agriculturae Fenniae 28: 13-19.

Mukula, J. \& Rantanen, O. 1989b. Climatic risks to the yield and quality of field crops in Finland. III Winter Rye 1969-1986. Annales Agriculturae Fenniae 28: $3-11$.

Peltonen-Sainio, P. 1991. Effect of moderate and severe drought stress on the pre-anthesis development and yield formation of oats. Journal of Agricultural Science in Finland 63: 379-389.

Peltonen-Sainio, P., Rajala, A. \& Kontturi, M. 2003. Development and growth of barley stands determining malting quality: coping growing conditions with crop management. In: Proceedings of the 29th EBC Congress, Dublin, Ireland. p. 116-124.

Plant Production Inspection Centre 1994-2001. Grain quality bulletin. Plant Production Inspection Centre, Grain Laboratory, Helsinki, Finland.

Saarikko, R. 2000. Applying a site based crop model to estimate regional yields under current and changed climates. Ecological Modelling 131: 191-206.

Stephenson, D.B., Paven, P. \& Bojariu, R. 2000. Is the North Atlantic Oscillation a random walk? International Journal of Climatology 20: 1-18.

Tashiro, T. \& Wardlaw, I.F. 1991. The effect of high temperature on kernel dimensions and the type and occurrence of kernel damage in rice. Australian Journal of Agricultural Research 42: 485-496.

Thornes, J.E. \& Stephenson, D.B. 2001. How to judge the quality and value of weather forecast products. Meteorological Applications 8: 307-308.

Westgate, M.E., Passioura, J.B. \& Munns, R. 1996. Water status and ABA content of floral organs in droughtstressed wheat. Australian Journal of Plant Physiology 23: 763-772. 
Hollins, P.D. et al. Relationships between climate and winter cereal grain quality

\title{
SELOSTUS
}

\section{Sään vaikutus syysviljojen hehtolitran painoon ennusteen laadinnan näkökulmasta}

\author{
Philip Hollins, Peter Kettlewell, Pirjo Peltonen-Sainio ja Mark Atkinson \\ Harper Adams Yliopisto, Iso-Britannia ja MTT (Maa- ja elintarviketalouden tutkimuskeskus)
}

Useat tutkimukset ovat osoittaneet erilaisten säätekijöiden vaikutuksia viljojen satomääriin, mutta harvemmin laatuominaisuuksiin. Tämän tutkimuksen tarkoituksena oli mallintaa syysvehnän ja -rukiin hehtolitran painon vuotuista vaihtelua kuukausittaisten lumensyvyys-, sadanta-, säteily- ja lämpötilatietojen perusteella. Tutkimus perustui pääosin vuosina 19712001 kerättyyn Kasvintuotannon tarkastuskeskuksen Viljalaboratorion aineistoon.

Lumensyvyys maaliskuussa yhdessä kesä- ja heinäkuun säteilymäärien kanssa selittivät $66 \%$ rukiin hehtolitran painon vuosivaihtelusta. Syysvehnällä $62 \%$ samasta vaihtelusta oli selitettävissä tammikuun lumensyvyydellä, kesäkuun säteilymäärällä ja elokuun lämpötilalla. Lumensyvyyden ja hehtolitran painon välinen yhteys selittynee pääosin sillä, kuinka aikaisin kasvukausi käynnistyy talven jälkeen - erityisesti kuinka paljon sadonkorjuu viivästyy kasvuun lähdön viivästymisen seurauksena. Säteilymäärän vaikutus on puolestaan yhteydessä kasvin kykyyn kerryttää yhteyttämistuotteita käytettäväksi niin satopotentiaalin rakentamiseen ennen tähkälle tuloa kuin myöhemmässä vaiheessa jyvien täyttämiseen. Näille kuvaileville malleille saatiin karkea tilastolli- nen merkitsevyys, vaikkakin poikkeamia ilmeni kohtuullisesti hehtolitranpainon ja säätekijöiden välisiä yhteyksiä kuvattaessa.

Tutkimuksessa selvitettiin myös mahdollisuutta kehittää hehtolitran painoa kuvaava ennustemalli. Ennustemalli olisi luonnollisesti sitä arvokkaampi mitä aikaisemmin ennustettavaa laatuominaisuutta kyettäisiin ennakoimaan riittävällä varmuudella jo ilmenneen sään perusteella. Ristiintaulukointia käyttäen arvioitiin, kuinka täsmällisesti heinäkuun alkuun mennessä ilmenneen sääaineiston perusteella onnistuttiin ennustamaan hehtolitran painoltaan keskiarvon ylittäneet ja alittaneet tapaukset. Kansallisen hehtolitranpainon ennustaminen osoittautui mahdolliseksi aineiston perusteella, mutta vain tilanteessa, jos säädataa oli kertynyt myös pitkälti jyväntäyttymisjaksolta. Siten hehtolitran painon aikainen ennustaminen ei osoittautunut perustelluksi kuukausittaisia säätekijöiden keskiarvotietoja käytettäessä. Ennustettavuus saattaisi kuitenkin parantua olennaisesti, jos malli nojaisi kuukausikeskiarvojen sijaan viljojen kehityksen ja kasvun kannalta keskeisimpien pääkasvujaksojen sääoloihin. 